\title{
Investigating the Distribution of Selected Major and Trace Metals in Lithogenic Environment near Cement Factory, Mekelle, Ethiopia
}

\author{
Samuel Estifanos
}

Department of Earth Sciences, College of Natural and Computational Sciences, Mekelle University, Mekelle, Ethiopia. Email:sambersih@yahoo.com

Received October 21 $1^{\text {st }}, 2013$; revised November $23^{\text {rd }}, 2013$; accepted December $18^{\text {th }}, 2013$

Copyright (C) 2014 Samuel Estifanos. This is an open access article distributed under the Creative Commons Attribution License, which permits unrestricted use, distribution, and reproduction in any medium, provided the original work is properly cited. In accordance of the Creative Commons Attribution License all Copyrights @ 2014 are reserved for SCIRP and the owner of the intellectual property Samuel Estifanos. All Copyright (C) 2014 are guarded by law and by SCIRP as a guardian.

\begin{abstract}
Sixteen physicochemical parameters including four major and ten trace metals were analyzed for seven top soil and six top stream sediment samples collected around the vicinity of cement factory in Mekelle, Ethiopia. Water and aqua regia extraction techniques were deployed to determine the water soluble and near total concentration of the metals in the samples. Water extraction results verified the magnitude of loading of the metals from anthropogenic sources. The mean values of the water soluble metals are found to exceed the reference values except for $\mathrm{Ca}$ and $\mathrm{Zn}$ in both lithogenic media indicating the severity of pollution. Spatial distribution of the metals suggested that cement factory dust and traffic emissions represent the most important pollutant sources for the investigated area. The mean proportion of the major and trace metals in the water soluble phase of soil can be put on a descending order as: $\mathrm{Mg}(57.76 \%)>\mathrm{Fe}>\mathrm{Ca}>\mathrm{K}>\mathrm{Na}>\mathrm{Mn}(3.77 \%)$ and $\mathrm{Mo}(53.17 \%)>\mathrm{Cu}>\mathrm{Co}>\mathrm{As}>$ $\mathrm{Ni}>\mathrm{Zn}>\mathrm{Pb}>\mathrm{Cr}(5.02 \%)$ respectively. The order of major metals is almost reverse in the case of the stream sediment with slight difference in the order of the trace metals. Factor analysis has revealed that the first factor represents the contribution of metals ( $\mathrm{Mn}, \mathrm{Cr}, \mathrm{As}, \mathrm{Co}, \mathrm{Zn}, \mathrm{Na}, \mathrm{K}, \mathrm{Cu}, \mathrm{Pb}$ and $\mathrm{Ni}$ ) from local anthropogenic activities, whereas the second factor represents the contribution of metals ( $\mathrm{Na}, \mathrm{Fe}, \mathrm{Cu}, \mathrm{Pb}, \mathrm{Ni}, \mathrm{Ca}, \mathrm{As}, \mathrm{Co}, \mathrm{Zn}$ and Mo) from both lithogenic and anthropogenic origins. Third factor consists of $\mathrm{Ca}, \mathrm{Mo}, \mathrm{Mg}$, and $\mathrm{Fe}$ from geogenic source of the local geology. It is spatially evident that the cement dust emission has an impact on the soil's Cr, Co, Mo and Ni content which drastically decreases downstream. The spatial pattern of $\mathrm{Cu}, \mathrm{Pb}$, As, Zn and Co shows significant association with the cement dust and loadings from the traffic movement on the road.
\end{abstract}

\section{KEYWORDS}

Metals; Geochemical Extraction; Cement Factory; Dust Emission; Factor Analysis

\section{Introduction}

Dust emitted from cement factories falls on plants and soils with consequent modification of soil properties through reactions between the contents of the dust and water molecules to form various products. This causes soil degradation with respect to changes in soil structure, exchangeable bases and cation exchange capacity affecting the soil fertility [1]. The effect of particulate pollutants from cement industries on soil and vegetation properties has become the focus of many researches in relation to the effect of gaseous pollutants [2-10]). These researches and others have recognized that cement dust contain trace quantities of heavy metals such as zinc, iron, manganese, copper and cobalt derived from the raw materials of cement production. Soil and subsequent stream sediment are the major lithogenic media to sink such heavy metals released into the environment by aforementioned anthropogenic activities.

In addition to getting an insight into heavy metal speciation and bioavailability, characterization of soil's metal content helps to gain knowledge of the source of contamination and associated environmental and health 
risks that serve as basis for remediation of contaminated soil. The pathway of heavy metals to plants is mainly via adsorption and/or absorption which refer to binding onto the surface and penetration into the inner matrix of soil minerals respectively. In investigating the effects associated with major and trace metals that result from natural or manmade activities, the bio-available fraction of the total elemental content in soil and sediment must be identified. This is because total concentrations do not necessarily explain the bioavailability of metals in sediment and soil. Water soluble fraction consists of metals which are comparatively labile, highly mobile and potentially bioavailable [11]. The leaching of metals from this fraction is, thus, a major ecotoxicological and environmental concern [12]. According to [13], there are a number of approaches developed to determine the bioavailable pools of metals, the simplest one of which is measuring metal concentrations in solutions obtained by chemical extraction (including water-extraction). However, none of them can satisfactorily describe the bioavailable pools due to the varying diversity in physicochemical characteristics, metal behavior, exposure routes and uptake mechanisms [13,14]. Although there are growing records that are extractable, rather than total, metal levels provide more meaningful results in soil pollution and toxicity studies, there is no consensus on what the most suitable technique should be [15].

Factor analysis is one of the statistical techniques that help in interpretation of geochemical data by revealing the factors responsible for the overall variability pattern. Factor analysis technique enables reducing the data to small set of factors that represent the underlying pattern of relationship among the metals providing information on the strength of a particular metal in a factor (loading), the amount of the total variability of each metals explained in a factor (communality) and the amount of total data explained in each model (eigen values in percent). The factors to be selected should have Eigen values greater than unity. The first few factors that account for most data variability are to be used in interpreting the natural or/and anthropogenic sources of metals.

The main purpose of this research is to examine the degree and extent of the impact of dust emission from a cement factory and vehicular movement on the distribution of selected major and trace metals in soil and stream sediments in the downwind and downstream vicinity. Thus this paper presents geochemical analysis and factor analysis results to reveal the metals' loading on the water soluble portions of soil and stream sediment materials due to natural and/or anthropogenic causes. The cement industry under consideration has been in operation since 2000. The factory is suited on the foot of Messebo hill which encompasses the major raw materials for cement production. The pollution assessment in this paper would help to discriminate the existing major and trace metals in soil and stream sediments which can possibly be attributed to the dust emission of the factory.

\section{Location and Description of the Area}

The study area is located at about $10 \mathrm{~km}$ NW of Mekelle City close to the Mekelle-Hagerselam asphalt road (Figure 1). It is situated at the downthrown part of Messebo normal fault which has a general trend of NESW direction. The dominant land use type in the study area is farm land with elongated village settlements. The geology of the area is characterized by sedimentary formation which is part of the Mesozoic Mekelle outlier, intruded by series of dolerite sills and dikes. The area of investigation falls on the western side of the cement industry where the dust predominantly blows to driven by the wind and the drainage joins the main stream, Ilalla which receives rainwater annually. The hydrogeology of the area is characterized by fracture type aquifers coupled with basaltic intrusions and limestone karstification. Wind in the Mekelle area normally blows from the SE to NW in the dry season, nine months of the year (September up to May) and reverses its direction in the rainy season i.e. June to August [16] (Figure 2).

\section{Materials and Methods}

Soil and stream sediment sampling was conducted in the western vicinity of Messebo cement factory in March, 2012 (Figure 1). Six soil composite samples from the farmland and seven stream sediment composite samples from a gully draining the farm land were collected each weighing $1 / 2 \mathrm{Kg}$. The main road serves as divide line between the soil and stream sediment sampling. The samples were carefully taken from the top $15 \mathrm{~cm}$ part of the sampling spots. Rock fragments and organic matter were removed on spot. All the samples were subjected to geochemical laboratory at Mekelle University for physicochemical analysis. Three subsamples were prepared from each sample weighing one and ten grams after sieving to $<2 \mathrm{~mm}$ size. Two one-gram subsamples were digested by aqua regia (nitric acid + hydrochloric acid, in a 1:3 volume ratio) prior to determining the major cations by atomic absorption spectrometry (AAS: varian spectrometer AA-400, flame atomic absorption spectrometer, stand alone system) and trace elements by Unicam 929AA Spectrophotometer respectively. The procedure is similar for both purposes in that each one gram sample was mixed with $20 \mathrm{ml}$ aqua regia stirring at $100^{\circ} \mathrm{C}$ for 20 minutes heated on a hot plate. Then $20 \mathrm{ml}$ of $0.1 \mathrm{~N} \mathrm{HC1}$, prepared by a mixture of $8.2 \mathrm{ml}$ concentrated HC1 and $1000 \mathrm{ml}$ distilled water, was added drop by drop to 


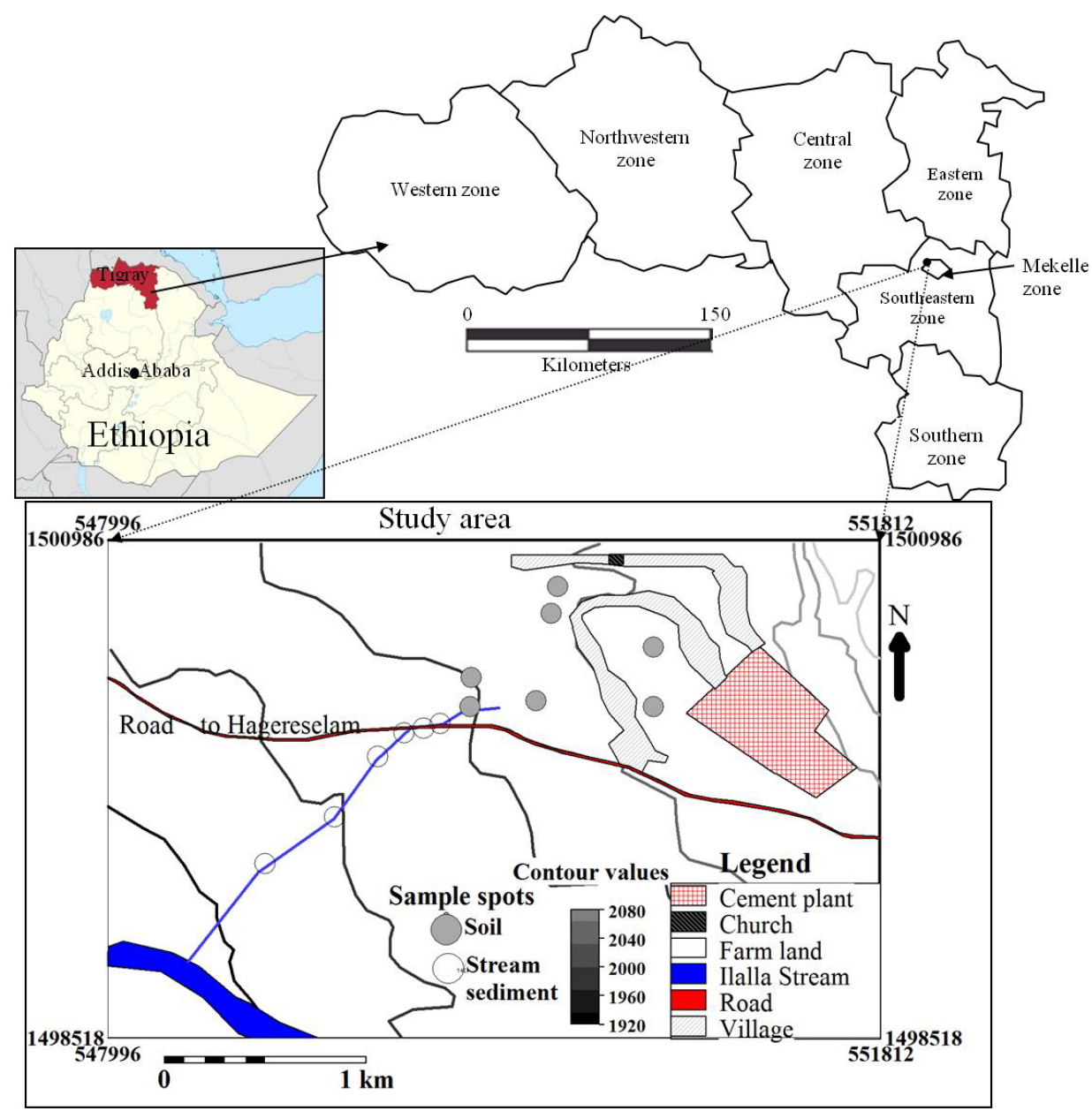

Figure 1. Location map of study area and sampling spots.

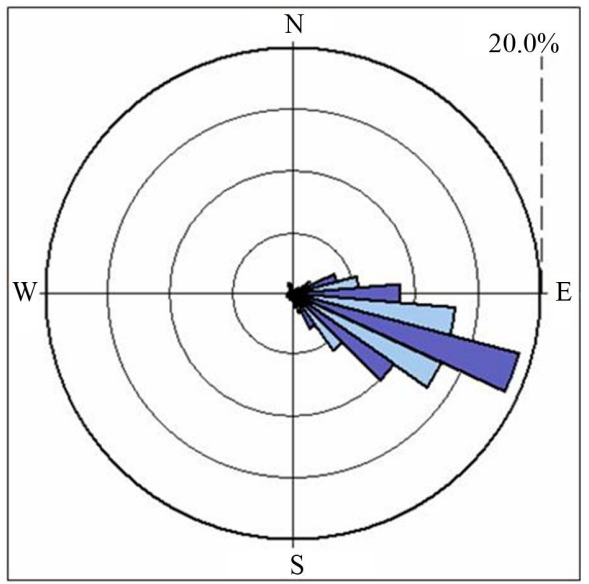

Figure 2. Predominant wind direction around Mekelle (January to July, 2005).

the digested samples and shaken for 2 minutes. The resulting solution was filtered by adding distilled water till the filtrate gets $50 \mathrm{ml}$ volume before cation and trace metals' measurements were done by respective atomic absorption spectrometry instruments. In both cases, ICP multielement standard solution IV UN-2031 was used. On the other hand, the 10-gram subsample of each sample was treated with de-ionized water in a $1 \mathrm{~g} / 10 \mathrm{ml}$ soil/water ratio, shaken for 2 hours and filtered prior to analysis using the same instruments to determine the cations in water soluble phases. Repeat analyses on three randomly selected samples were performed and reagent blanks and standards were used to assure quality control of analysis. The precision and bias were generally $<10 \%$. For comparison with the geochemical background values of metals, five uncontaminated surface soil samples were collected from undisturbed area at about $6 \mathrm{~km}$ distance from the study area where anthropogenic activities are minimal and are believed to represent geological background with reference to heavy metals. These samples were digested with aqua regia in the same procedure as the main samples and the analysis results were used for comparison purposes as reference to assess the pollution of the study area.

The geochemical analytical datasets for the water and 
the difference between aqua regia and water extraction were statistically treated using SPSS version 16.0 software. Such subtraction approach is supposed to enhance the metals concentration attached to water soluble, amorphous and crystalline/primary rocks mineral components. In order to closely examine the distribution, relationships and possible sources of the metals in the water soluble and water insoluble phases of soil and stream sediment minerals, separate factor analysis were conducted for fourteen variables in both datasets. The factor analyses were performed by using principle component analysis (PCA) and computing the Eigen values. The rotation of principle components was carried out by the varimax method. The factor loadings, which can be regarded as combination between the elements, were then computed after rotating the original principal component solution. In this study, factors with Eigen values greater than 1 were retained and only variables with loadings greater than 0.60 and highest value were considered as having significant association under a particular factor.

\section{Results and Discussion}

\subsection{Physiochemical Properties of the Lithogenic Media}

The result of geochemical analysis of the major and trace metals of the soil and stream sediment samples are summarized in Table 1. The data comprises of concentration of water soluble metals and near total aqua-regia extraction values of the lithogenic media near the cement factory as compared to background ranges of the metals. The texture of the soil ranges from sandy loam, to silty clay in most cases. The soil and stream sediments are calcareous in nature with average Ca content of 370.41 and $135.04 \mathrm{ppm}$ in aqua regia and water extractions respectively. Moreover, their $\mathrm{pH}$ values range from 8.75 to 9.51 while the EC values range from 102.00 to 326.45 $\mu \mathrm{S} / \mathrm{cm}$ with an average value of $193.72 \mu \mathrm{S} / \mathrm{cm}$. This shows that the lithogenic media is saline to alkaline compared to reference media with mean $\mathrm{pH}$ value of 7.48. High EC values in soil indicate the concentration of salt in the soil. Industrial saline wastes and irrigation are the main human activities that add salts to the soil [17]. There is no irrigation activities in the study area and thus the higher values of EC have to be related to the dust emission from the cement factory.

\subsection{Distribution of the Metals}

The distribution of the metals in the lithogenic media of the study area is assessed by examining the relative proportion of the total concentrations in the water soluble and residual (difference between aqua regia and the wa- ter soluble values) portions. These two phases are believed to explain the natural and/or anthropogenic attributes to the source and mobilization of the associated cations. All the fourteen cations under consideration exist in the residual (water insoluble) phase for more than half of their total concentration as determined by aqua regia extraction. Manganese, chromium and lead have higher distribution in the residual phases while magnesium exhibited the highest concentration proportion in the water soluble phase. The proportion of the mean values of the major and trace metals in the water soluble phase is found to have a decreasing order as: $\mathrm{Mg}>\mathrm{Fe}>\mathrm{Ca}>\mathrm{Na}>$ $\mathrm{K}>\mathrm{Mn}$ and $\mathrm{Ni}>\mathrm{Mo}>\mathrm{Cu}>\mathrm{Co}>\mathrm{As}>\mathrm{Zn}>\mathrm{Pb}>\mathrm{Cr}$ respectively (Figures 3 and 4 ). It is well perceived that metals might undergo crystallization hindering their water solubility due to the fact that in cement dust calcium silicate and calcium aluminates are present in the form of colloidal gels. The crystallization and solidification develop a hard crust-causing low yield crops by affecting the mobility of the nutrient metals in soil [3].

The water soluble and residual proportions of metals in both soil and stream-sediment media generally showed similar mean values of $\mathrm{Ca}, \mathrm{Fe}, \mathrm{Cr}, \mathrm{Pb}$, As and $\mathrm{Zn}$ as well as Co, $\mathrm{Zn}$, Mo respectively (Table 2). The soil experienced higher proportions of $\mathrm{K}, \mathrm{Mg}, \mathrm{Cu}, \mathrm{Co}$ and $\mathrm{Mo}$ in the water soluble phase than do the streamsediment which has in turn higher proportion of $\mathrm{Na}, \mathrm{Mn}$ and $\mathrm{Ni}$. The water soluble proportion (mobility) of the metals in soil ranges from below the detection limit of the instrument for $\mathrm{Cr}$ up to $75 \%$ for Mg. Likewise the proportion of the metals in stream sediment has minimum value for $\mathrm{Cr}$ and maximum of $76 \%$ for Mn (Table 2). Generally, the mean proportion of the major and trace metals in the water soluble phase of soil can be put on a decreasing order as: $\mathrm{Mg}(57.76 \%)>\mathrm{Fe}>\mathrm{Ca}>\mathrm{K}>\mathrm{Na}>\mathrm{Mn}(3.77 \%)$ and $\mathrm{Mo}(53.17 \%)>\mathrm{Cu}>\mathrm{Co}>\mathrm{As}>\mathrm{Ni}>\mathrm{Zn}>\mathrm{Pb}>$ $\mathrm{Cr}(5.02 \%)$ respectively. This order is not maintained in the case of the stream sediment where the major metals have such descending order as: $\mathrm{Na}(54.33 \%)>\mathrm{Mn}>\mathrm{Fe}>$ $\mathrm{Ca}>\mathrm{Mg}>\mathrm{K}(18.78 \%)$ while the trace metals have such order as: $\mathrm{Ni}(51.45 \%)>\mathrm{Mo}>\mathrm{Zn}>\mathrm{Cu}>\mathrm{As}>\mathrm{Co}>\mathrm{Pb}>$ $\mathrm{Cr}(0.02 \%)$. In both cases, $\mathrm{Pb}$ and $\mathrm{Cr}$ have the lowest whereas Mo has higher proportion in the water soluble phase. Similar results were obtained by [12] and [18] in the water-soluble fraction of lake sediments and soil respectively.

\subsection{Pollution Assessment Result}

It is evident that all the metals in the near total analysis (aqua regia extraction) are above the background values used as reference to assess the pollution status of the study area. It is also possible to note that the mean values of the water soluble extraction of all the metals is higher 
Table 1. Concentration of metals (ppm except for $\mathbf{p H}$ and EC) in water and aqua regia extraction phases of the lithogenic media around the cement factory compared to common ranges in unaffected area.

\begin{tabular}{|c|c|c|c|c|c|c|c|c|c|c|c|}
\hline \multirow{2}{*}{ Metals } & \multicolumn{4}{|c|}{ Water Extraction Values } & \multicolumn{4}{|c|}{ Aqua-regia Extraction Values } & \multicolumn{3}{|c|}{$\begin{array}{l}\text { Heavy metals concentration } \\
\text { in soils of reference area }\end{array}$} \\
\hline & Min & $\operatorname{Max}$ & Mean & Std. Dev. & Min & $\operatorname{Max}$ & Mean & $S t D v$ & $\operatorname{Max}$ & Min & Mean \\
\hline $\mathrm{Na}$ & 42.00 & 105.00 & 80.98 & 22.70 & 162.00 & 441.00 & 255.55 & 106.29 & 56.00 & 23.00 & 40.33 \\
\hline $\mathrm{K}$ & 1.00 & 6.00 & 3.42 & 1.63 & 7.50 & 26.00 & 14.76 & 6.39 & 5.60 & 1.50 & 3.13 \\
\hline $\mathrm{Ca}$ & 102.00 & 203.00 & 135.04 & 34.65 & 208.00 & 485.33 & 370.41 & 74.49 & 101.00 & 86.00 & 95.00 \\
\hline $\mathrm{Mg}$ & 38.00 & 112.00 & 64.42 & 24.93 & 90.67 & 182.00 & 146.62 & 24.59 & 21.00 & 12.00 & 16.00 \\
\hline $\mathrm{Fe}$ & 201.00 & 512.00 & 330.15 & 87.86 & 745.00 & 1012.00 & 862.04 & 70.37 & 202.00 & 101.00 & 143.00 \\
\hline $\mathrm{Mn}$ & 0.01 & 5.20 & 1.03 & 1.69 & 1.05 & 57.00 & 21.96 & 21.55 & 0.26 & 0.01 & 0.14 \\
\hline $\mathrm{Cu}$ & 12.00 & 61.00 & 42.23 & 12.95 & 74.00 & 164.00 & 114.90 & 23.23 & 3.10 & 2.50 & 2.80 \\
\hline $\mathrm{Pb}$ & 0.01 & 1.50 & 0.75 & 0.43 & 4.00 & 18.00 & 10.52 & 4.65 & 0.63 & 0.42 & 0.53 \\
\hline As & 4.00 & 58.00 & 34.69 & 15.90 & 77.00 & 143.00 & 113.85 & 19.25 & 2.31 & 0.98 & 1.62 \\
\hline Co & 2.00 & 61.00 & 18.73 & 18.81 & 38.00 & 82.00 & 55.14 & 13.29 & 0.93 & 0.56 & 0.74 \\
\hline $\mathrm{Zn}$ & 9.00 & 61.00 & 40.50 & 16.17 & 113.00 & 167.00 & 135.58 & 16.30 & 98.00 & 11.50 & 43.49 \\
\hline $\mathrm{Ni}$ & 3.00 & 41.00 & 28.15 & 10.37 & 46.00 & 103.50 & 73.86 & 14.92 & 0.41 & 0.12 & 0.25 \\
\hline Mo & 12.00 & 53.00 & 28.85 & 14.72 & 32.00 & 113.00 & 60.54 & 23.26 & 3.20 & 1.80 & 2.43 \\
\hline $\mathrm{EC}, \mu \mathrm{S} / \mathrm{cm}$ & 102.00 & 326.45 & 193.72 & 68.22 & & & & & 101.00 & 103.00 & 102.00 \\
\hline
\end{tabular}
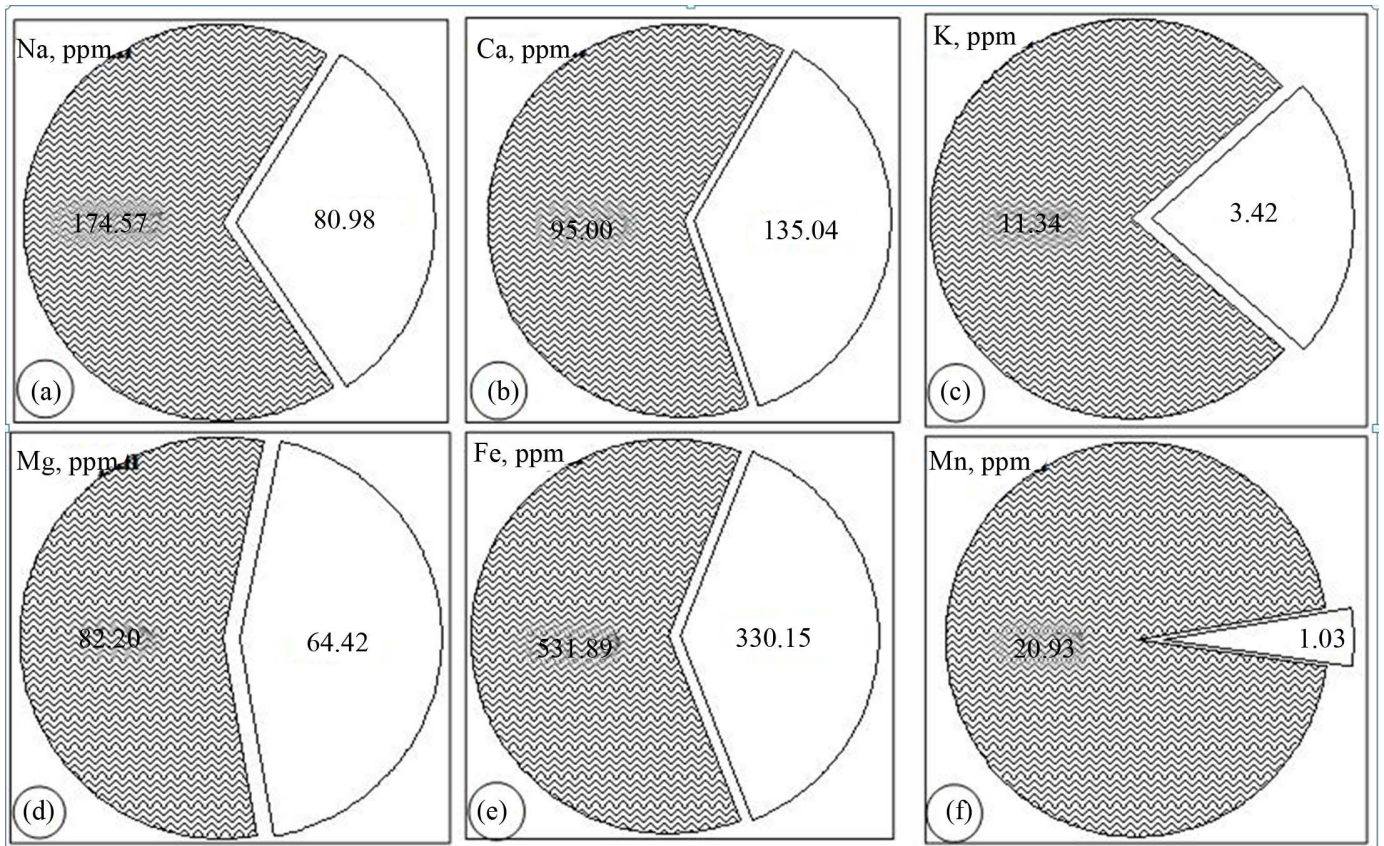

Figure 3. Pie diagrams showing the distribution of the major metals in water soluble (shaded) and residual phases. 

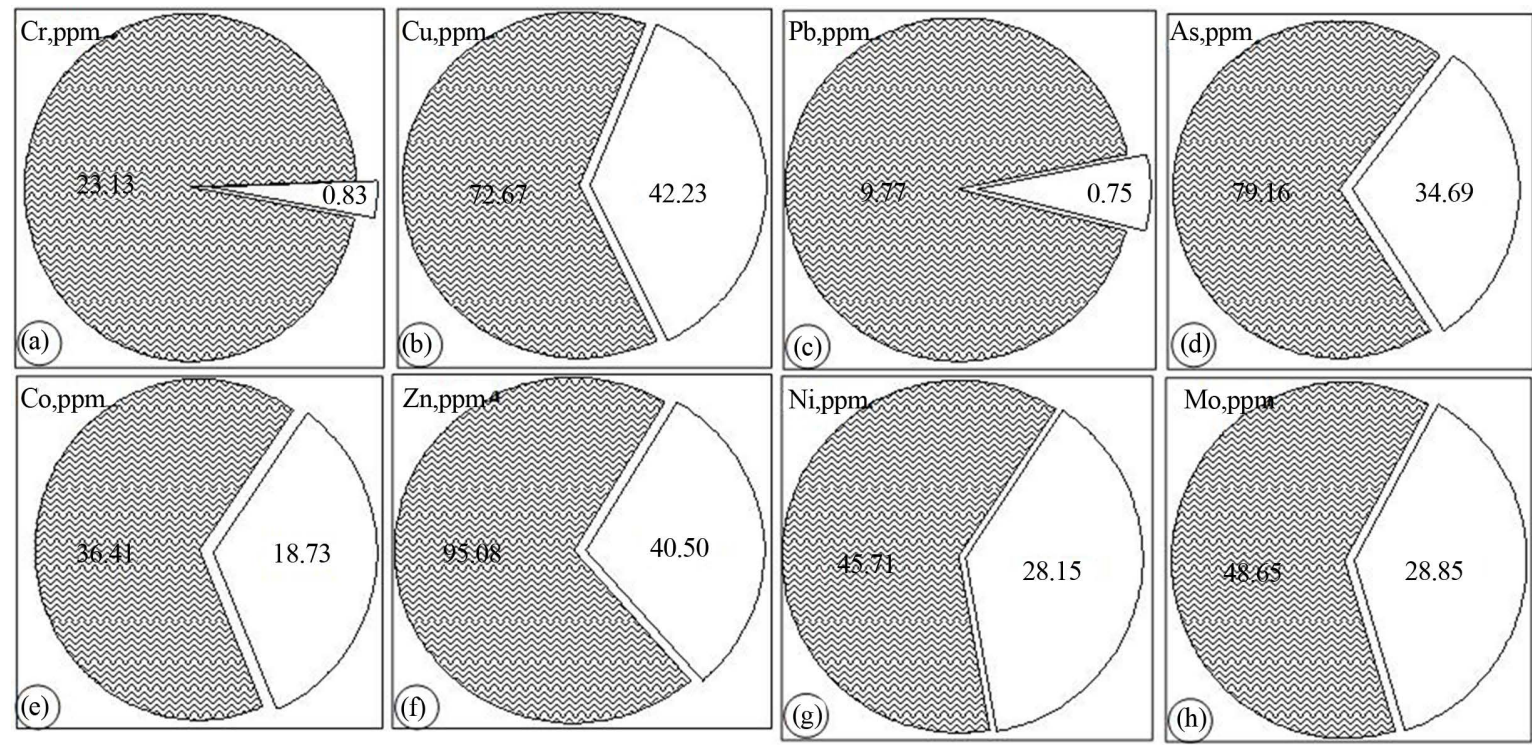

Figure 4. Pie diagrams showing the distribution of the trace metals in water soluble (shaded) and residual phases.

Table 2. Summary of metals distribution in water and residual phases of soil and stream-sediment.

\begin{tabular}{|c|c|c|c|c|c|c|c|c|c|c|c|c|}
\hline \multirow{3}{*}{ Metals } & \multicolumn{6}{|c|}{ Metals in Soil Phases } & \multicolumn{6}{|c|}{ Metals in Stream sediment Phases } \\
\hline & \multicolumn{3}{|c|}{ Residual Portion, ppm } & \multicolumn{3}{|c|}{ Water soluble Proportion, \%age } & \multicolumn{3}{|c|}{ Residual Portion, ppm } & \multicolumn{3}{|c|}{ Water soluble Proportion, \%age } \\
\hline & Min & $\operatorname{Max}$ & Mean & Min & Max & Mean & Min & $\operatorname{Max}$ & Mean & Min & Max & Mean \\
\hline $\mathrm{Na}$ & 85.30 & 372.00 & 254.07 & 10.54 & 50.41 & 23.57 & 60.00 & 107.00 & 81.83 & 42.47 & 62.96 & 54.33 \\
\hline $\mathrm{K}$ & 3.13 & 11.17 & 6.77 & 17.00 & 61.48 & 34.85 & 7.00 & 22.00 & 16.67 & 5.56 & 41.67 & 18.78 \\
\hline $\mathrm{Ca}$ & 131.00 & 331.33 & 249.26 & 27.91 & 58.68 & 39.23 & 100.00 & 314.00 & 219.17 & 24.52 & 51.92 & 35.41 \\
\hline Mg & 28.50 & 115.00 & 59.50 & 31.14 & 75.17 & 57.76 & 92.00 & 126.00 & 108.67 & 23.60 & 36.99 & 30.95 \\
\hline $\mathrm{Fe}$ & 323.00 & 701.00 & 487.79 & 23.30 & 61.32 & 41.24 & 413.00 & 726.00 & 583.33 & 28.26 & 49.39 & 35.67 \\
\hline $\mathrm{Mn}$ & 19.19 & 56.87 & 38.01 & 0.03 & 13.95 & 3.77 & 0.30 & 1.48 & 1.00 & 5.13 & 76.19 & 38.25 \\
\hline $\mathrm{Cr}$ & 14.88 & 54.50 & 34.22 & - & 15.94 & 5.02 & 5.67 & 12.60 & 10.19 & - & 0.04 & 0.02 \\
\hline $\mathrm{Cu}$ & 31.00 & 94.67 & 55.52 & 11.25 & 58.11 & 45.46 & 64.00 & 136.00 & 92.67 & 17.07 & 39.62 & 30.45 \\
\hline $\mathrm{Pb}$ & 3.97 & 8.47 & 6.21 & 0.25 & 20.60 & 8.87 & 10.98 & 16.50 & 13.92 & 2.56 & 8.50 & 6.16 \\
\hline As & 25.00 & 95.33 & 70.86 & 4.67 & 67.53 & 32.52 & 76.00 & 100.00 & 88.83 & 21.14 & 36.36 & 29.76 \\
\hline Co & 18.50 & 55.33 & 35.05 & 4.08 & 74.39 & 37.12 & 28.00 & 47.00 & 38.00 & 16.98 & 39.13 & 24.11 \\
\hline $\mathrm{Zn}$ & 59.50 & 138.00 & 97.43 & 6.49 & 50.62 & 29.41 & 69.00 & 116.00 & 92.33 & 15.94 & 43.90 & 32.28 \\
\hline $\mathrm{Ni}$ & 32.67 & 84.67 & 57.60 & 3.42 & 53.11 & 30.91 & 18.00 & 45.00 & 31.83 & 33.82 & 62.30 & 51.45 \\
\hline Mo & 15.00 & 60.00 & 32.71 & 37.50 & 73.21 & 53.17 & 23.00 & 36.00 & 30.50 & 32.08 & 50.00 & 38.38 \\
\hline
\end{tabular}

than the reference values except for $\mathrm{Ca}$ and $\mathrm{Zn}$ in both lithogenic media. However, $\mathrm{K}, \mathrm{Mn}, \mathrm{Cr}$, and $\mathrm{Pb}$ have low mean values in the water soluble portions close to the reference values (Figures 5(a) and (b)). Looking at the residual values, the stream sediments revealed to have higher $\mathrm{Mg}, \mathrm{Fe}, \mathrm{Cu}$ and $\mathrm{As}$ than the soil samples while $\mathrm{K}$, $\mathrm{Mn}, \mathrm{Cr}, \mathrm{Pb}, \mathrm{Co}$ and Mo showed comparable values in both media. On the other hand, the soil's residual fractions have higher $\mathrm{Na}, \mathrm{Ca}$ and $\mathrm{Ni}$ contents (Figure 5(c)). A study by [8] attributed relatively high soils content of metals including $\mathrm{Fe}, \mathrm{Zn}, \mathrm{Cu}, \mathrm{Pb}$ and $\mathrm{Cr}$ to anthropogenic sources of cement industry. [1] reported that $\mathrm{Ca}$ and $\mathrm{Na}$ enrichment was higher near the source of cement dust.

Major metals presence in water extraction depends on 


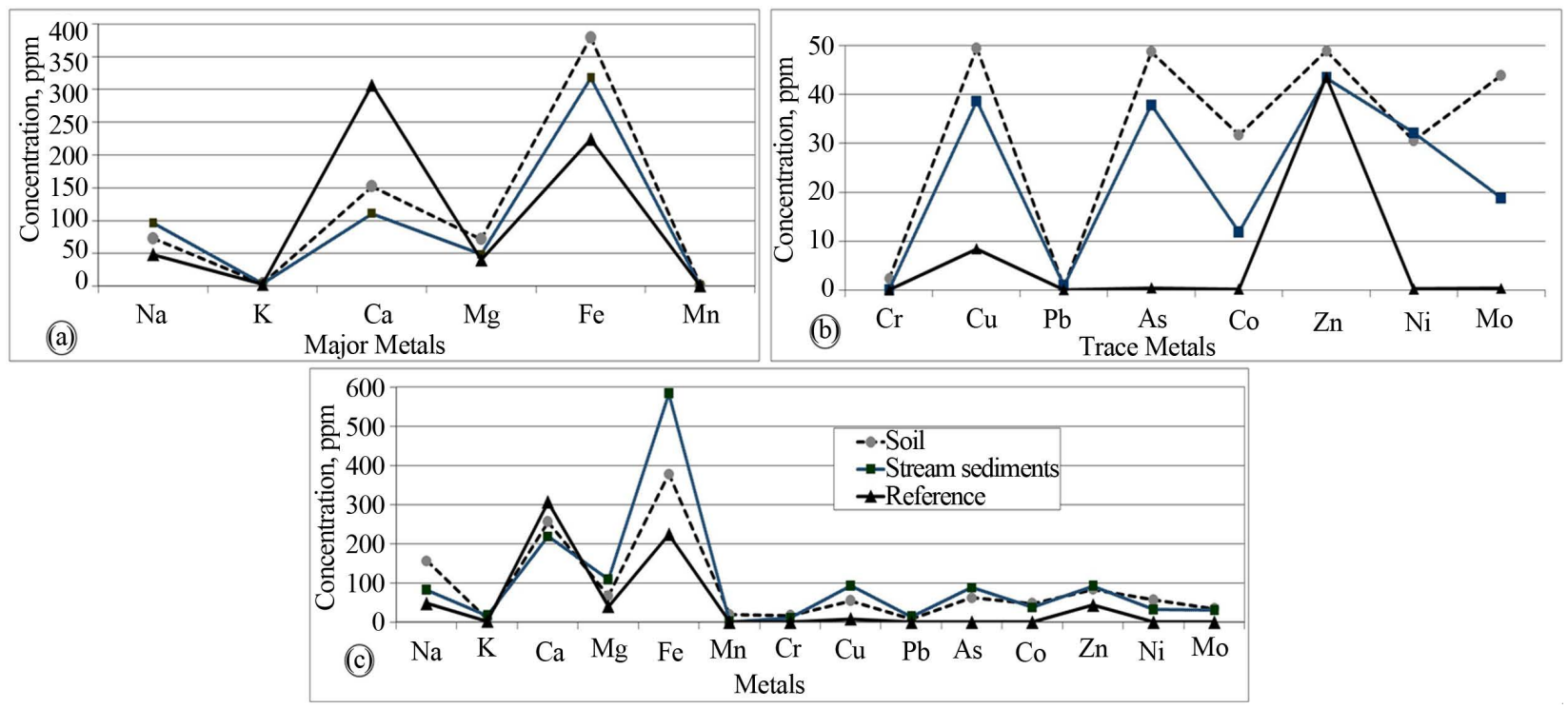

Figure 5. Comparison of water soluble extraction mean values, ppm, of major (a), trace (b) metals and residual values, ppm (c) of soil and stream sediment with background values.

the presence of salts hosting the cations. The water soluble portion of trace metals refers to the detached cations from their crystalline mineral structure or to anthropogenic loadings of the metals [19]. Detaching the trace metals from their minerals needs vigorous acid attack which is not common in nature unless there is acid mine drainage or as long term effect of acid rain. The soil samples address the immediate impact of the dust emission from the cement plants whereas the stream sediment represents the lithogenic materials in the creek (small tributary) drained from the farm land where the soil samples were collected on and transported through a bridged under a main road.

\subsection{Factor Analysis Results}

The result of the factor analysis for the water extraction and residual data is presented in Tables 3 and 4. The loadings of greater than 0.60 in the initial and rotated matrix are marked bold in the tables. The first factor components of water extraction data accounted for 33.52\% of the total variance respectively, while having high loadings on the elements $\mathrm{Mn}, \mathrm{Cr}$, As, Co and $\mathrm{Zn}$. About $42.66 \%$ of the total variance is accounted for by the first factor in the residual data with higher loading of $\mathrm{Na}, \mathrm{K}$, $\mathrm{Mn}, \mathrm{Cr}, \mathrm{Cu}, \mathrm{Pb}$ and $\mathrm{Ni}$ in the lithogenic media. This indicates the influence of local anthropogenic activities such as the cement factory and traffic movement [20-22]. It was noted that $\mathrm{Cr}$ and $\mathrm{Pb}$ in both media as well as $\mathrm{Mn}$ in the soil media have lowest water soluble proportions but are grouped under the anthropogenic factor. Moreover, the association of $\mathrm{Ni}$ and $\mathrm{Pb}$ with $\mathrm{K}$ was previously found to likely be due to anthropogenic factors [7]. This may imply the solidification effect of cement dust and/or incorporation in the particulates affecting water solubility of the metals. A study conducted by [23] attributed a factor with $\mathrm{Mn}, \mathrm{Cr}$ and As to anthropogenic source from cement dust while $\mathrm{Na}, \mathrm{K}$, Co, Zn and Ni to both cement dust and road traffic emissions in another factor. It explained a third factor to contain $\mathrm{Cu}$ and $\mathrm{Pb}$ specifically attributed to traffic emissions.

The second factor for water soluble data with $22.29 \%$ and for the residual data with $24.49 \%$ of the respective variances was composed by $\mathrm{Na}, \mathrm{Fe}, \mathrm{Cu}, \mathrm{Pb}$ and $\mathrm{Ni}$ as well as $\mathrm{Ca}$, As, Co, $\mathrm{Zn}$ and Mo loadings respectively. This factor implies high loadings of both natural and anthropogenic sources [23]. Presence of $\mathrm{Pb}, \mathrm{Fe}$ and $\mathrm{Zn}$ can indicate that dual sources have contributed to their concentrations [7]. [21] found the elements As to be controlled by parent factors, whereas $\mathrm{Ca}, \mathrm{Co}, \mathrm{Cr}, \mathrm{Cu}, \mathrm{Mn}, \mathrm{Ni}$, $\mathrm{Pb}$, and $\mathrm{Zn}$ by both anthropogenic and pedogenic factors. The third factor in the water extraction data accounts for $21.34 \%$ of the total variance was composed by Ca, Mo, $\mathrm{Mg}$, and Fe (after rotation). The respective factor in the residual data explains about $12 \%$ of the variance and is represented by $\mathrm{Fe}$ and $\mathrm{Mg}$ (defined after rotation). The third factor in both cases represents the weathering (pedogenic) results from geogenic source of the local geology characterized by carbonate and dolerite rocks. Fe, Ca and $\mathrm{Mg}$ are more associated to crustal elements, though the effect of anthropogenic sources could not be entirely ignored [24]. The fourth factor has no significance in both cases with weak loading of only $\mathrm{K}$ in the water extraction having the lowest communality (Table 3). In summary, factor 1 represents the contribution of metals ( $\mathrm{Mn}, \mathrm{Cr}, \mathrm{As}, \mathrm{Co}, \mathrm{Zn}, \mathrm{Na}, \mathrm{K}, \mathrm{Cu}, \mathrm{Pb}$ and $\mathrm{Ni}$ ) from local 
Investigating the Distribution of Selected Major and Trace Metals

in Lithogenic Environment near Cement Factory, Mekelle, Ethiopia

Table 3. Factor analysis result for water extraction results.

\begin{tabular}{|c|c|c|c|c|c|c|c|c|c|}
\hline \multirow{2}{*}{ Metals } & \multicolumn{4}{|c|}{ Component Matrix ${ }^{*}$} & \multicolumn{4}{|c|}{ Rotated Component Matrix ${ }^{* *}$} & \multirow{2}{*}{ Communalities } \\
\hline & 1 & 2 & 3 & 4 & 1 & 2 & 3 & 4 & \\
\hline $\mathrm{Na}$ & $(0.47)$ & 0.76 & $(0.40)$ & $(0.06)$ & 0.12 & $(0.47)$ & 0.71 & 0.48 & 0.90 \\
\hline $\mathrm{K}$ & $(0.10)$ & 0.46 & 0.23 & $(0.46)$ & $(0.09)$ & 0.11 & 0.10 & 0.68 & 0.09 \\
\hline $\mathrm{Ca}$ & $(0.47)$ & $(0.17)$ & 0.84 & 0.03 & $(0.95)$ & 0.24 & $(0.08)$ & 0.06 & 0.98 \\
\hline $\mathrm{Mg}$ & $(0.64)$ & $(0.08)$ & 0.67 & 0.22 & $(0.94)$ & 0.05 & 0.16 & $(0.05)$ & 0.90 \\
\hline $\mathrm{Fe}$ & $(0.47)$ & 0.66 & 0.33 & 0.34 & $(0.45)$ & 0.08 & 0.80 & 0.20 & 0.99 \\
\hline $\mathrm{Mn}$ & 0.81 & $(0.04)$ & 0.42 & $(0.34)$ & 0.29 & 0.79 & $(0.46)$ & 0.21 & 0.80 \\
\hline $\mathrm{Cr}$ & 0.67 & $(0.24)$ & 0.04 & 0.59 & 0.33 & 0.52 & $(0.02)$ & $(0.69)$ & 0.42 \\
\hline $\mathrm{Cu}$ & 0.31 & 0.73 & 0.50 & 0.20 & $(0.02)$ & 0.72 & 0.57 & 0.27 & 0.82 \\
\hline $\mathrm{Pb}$ & 0.15 & 0.69 & 0.15 & $(0.49)$ & 0.18 & 0.26 & 0.22 & 0.78 & 0.16 \\
\hline Co & 0.90 & $(0.12)$ & 0.37 & $(0.12)$ & 0.34 & 0.83 & $(0.41)$ & $(0.03)$ & 0.97 \\
\hline $\mathrm{Zn}$ & 0.80 & 0.30 & $(0.27)$ & 0.23 & 0.78 & 0.44 & 0.20 & $(0.15)$ & 0.79 \\
\hline $\mathrm{Ni}$ & $(0.02)$ & 0.75 & $(0.36)$ & 0.34 & 0.35 & $(0.08)$ & 0.81 & 0.09 & 0.56 \\
\hline Mo & 0.44 & 0.25 & 0.80 & 0.15 & $(0.22)$ & 0.93 & 0.10 & 0.08 & 0.89 \\
\hline Eigen value & 4.69 & 3.12 & 2.99 & 1.34 & 3.77 & 3.75 & 2.64 & 1.98 & \\
\hline$\%$ of Variance & 33.52 & 22.29 & 21.34 & 9.54 & 26.94 & 26.76 & 18.88 & 14.11 & \\
\hline$\%$ Cumulative & 33.52 & 55.81 & 77.15 & 86.70 & 26.94 & 53.70 & 72.58 & 86.69 & \\
\hline
\end{tabular}

Extraction Method: Principal Component Analysis. Rotation Method: Varimax with Kaiser Normalization. ${ }^{*}$ Rotation converged in 7 iterations. ${ }^{* *} 4$ Components extracted.

Table 4. Factor analysis result for residual extraction results.

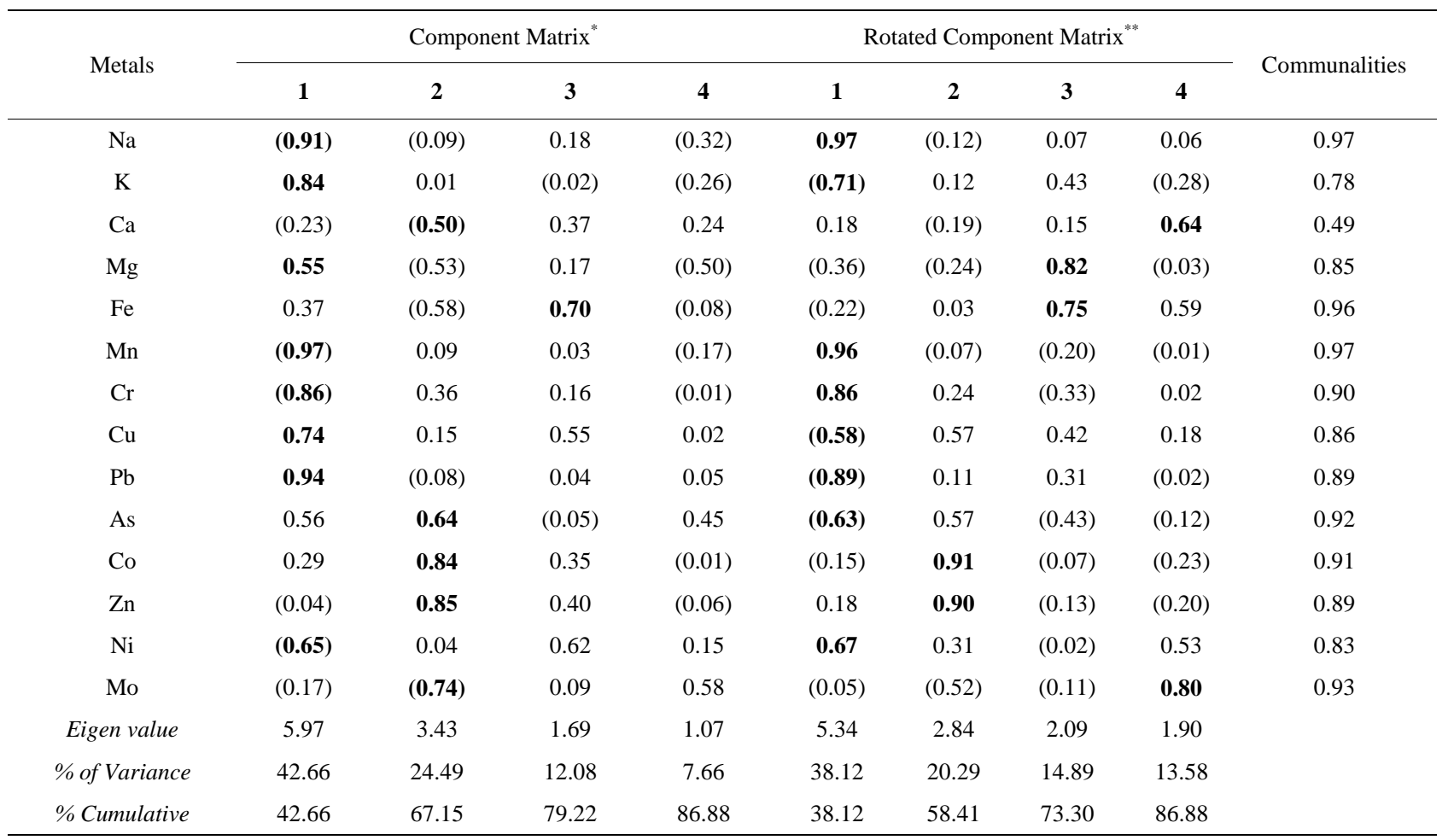

Extraction Method: Principal Component Analysis. Rotation Method: Varimax with Kaiser Normalization. ${ }^{*}$ Components extracted. ${ }^{* *}$ Rotation converged in 9 iterations. 
anthropogenic activities, where as factor 2 represents the contribution of metals ( $\mathrm{Na}, \mathrm{Fe}, \mathrm{Cu}, \mathrm{Pb}, \mathrm{Ni}, \mathrm{Ca}, \mathrm{As}, \mathrm{Co}$, $\mathrm{Zn}$ and Mo) from both lithogenic and anthropogenic origins. Factor 3 consists of $\mathrm{Ca}, \mathrm{Mo}, \mathrm{Mg}$, and Fe from geogenic source of the local geology.

\subsection{Spatial Analysis Result}

Spatial distribution of the metals suggested that cement factory dust and traffic emissions represents the most important pollutant source for the investigated area (Figures 6 and 7). The soil samples collected from the
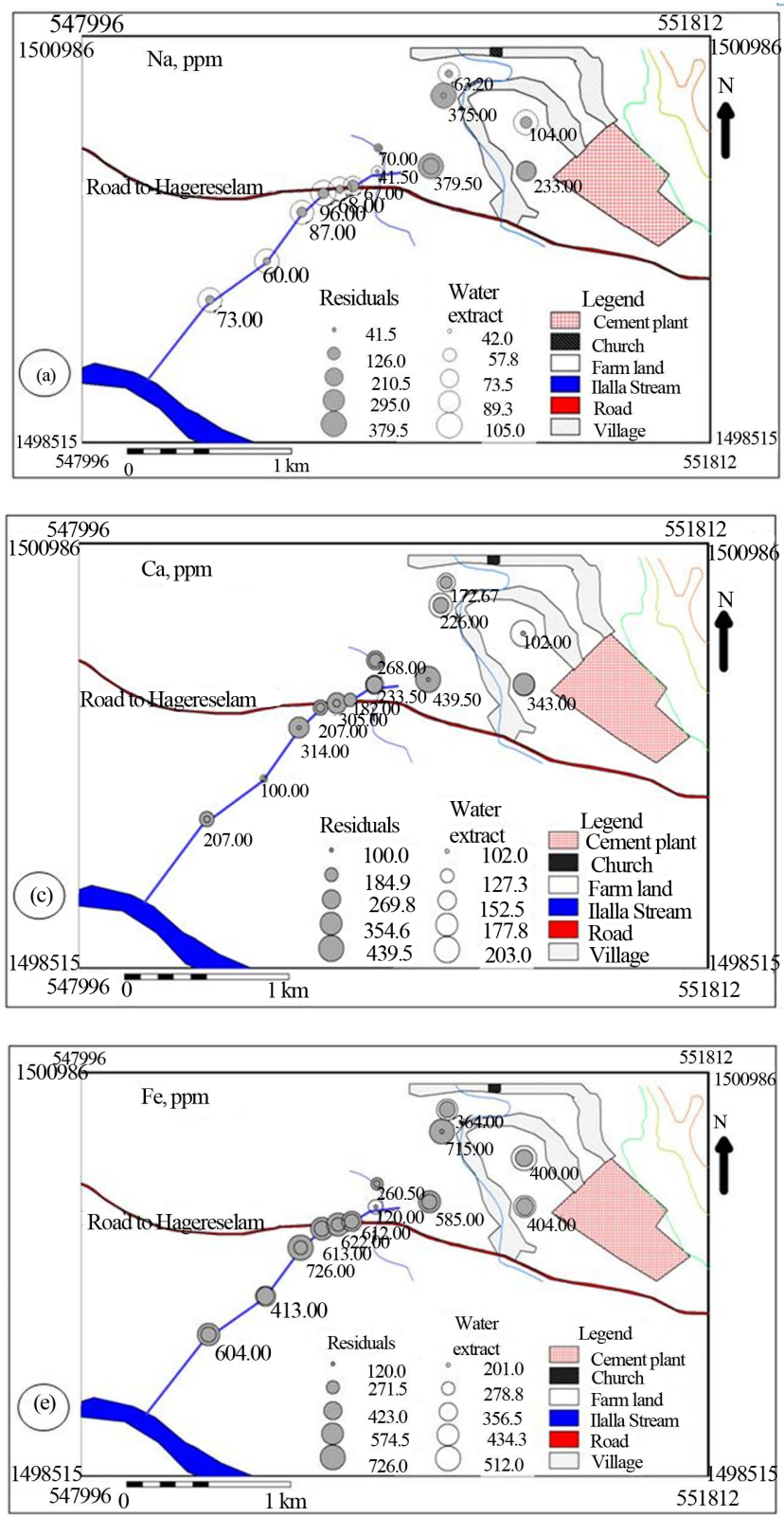

north western side of the cement factory towards which the wind predominantly blows is characterized by comparable water soluble values of $\mathrm{Na}, \mathrm{K}$ and $\mathrm{Mn}$ with stream sediment down stream side of the main road (Figures 6(a), (b) \& (f)). The farm soil has higher $\mathrm{Na}$ and $\mathrm{Mn}$ in the residual as well as higher $\mathrm{Ca}$ and $\mathrm{Mg}$ in the water soluble values that decreases down stream. This spatial trend is accompanied with comparable Ca and $\mathrm{Fe}$ and increasing $\mathrm{Mg}$ residual values downstream implying the effect of cement dust on the soil and doleritic rocks on the bank of the creek (Figures 6(a), (c)-(f)).
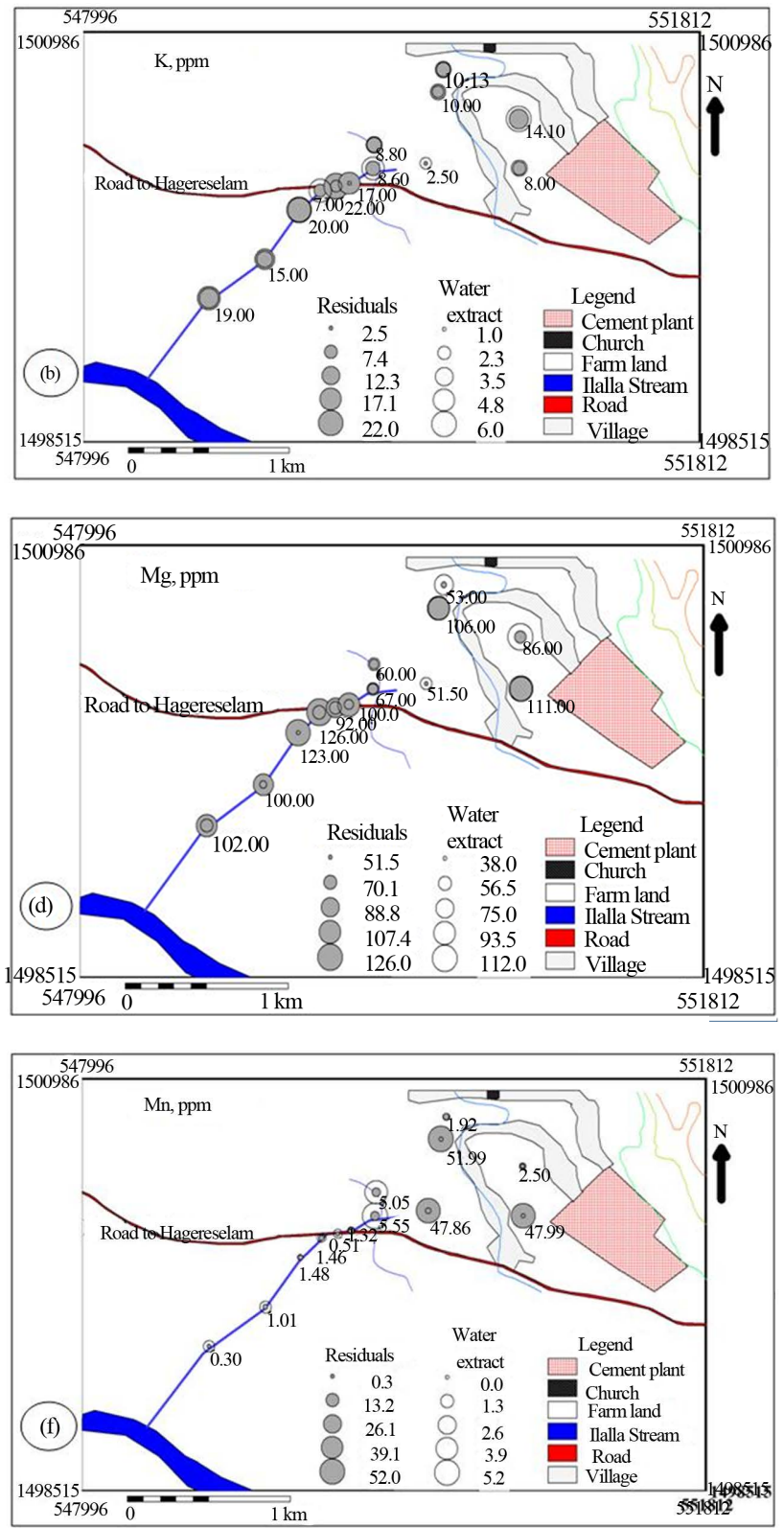

Figure 6. Post maps showing the spatial distribution of major cations in water soluble and residual portions of soil and stream sediments. 

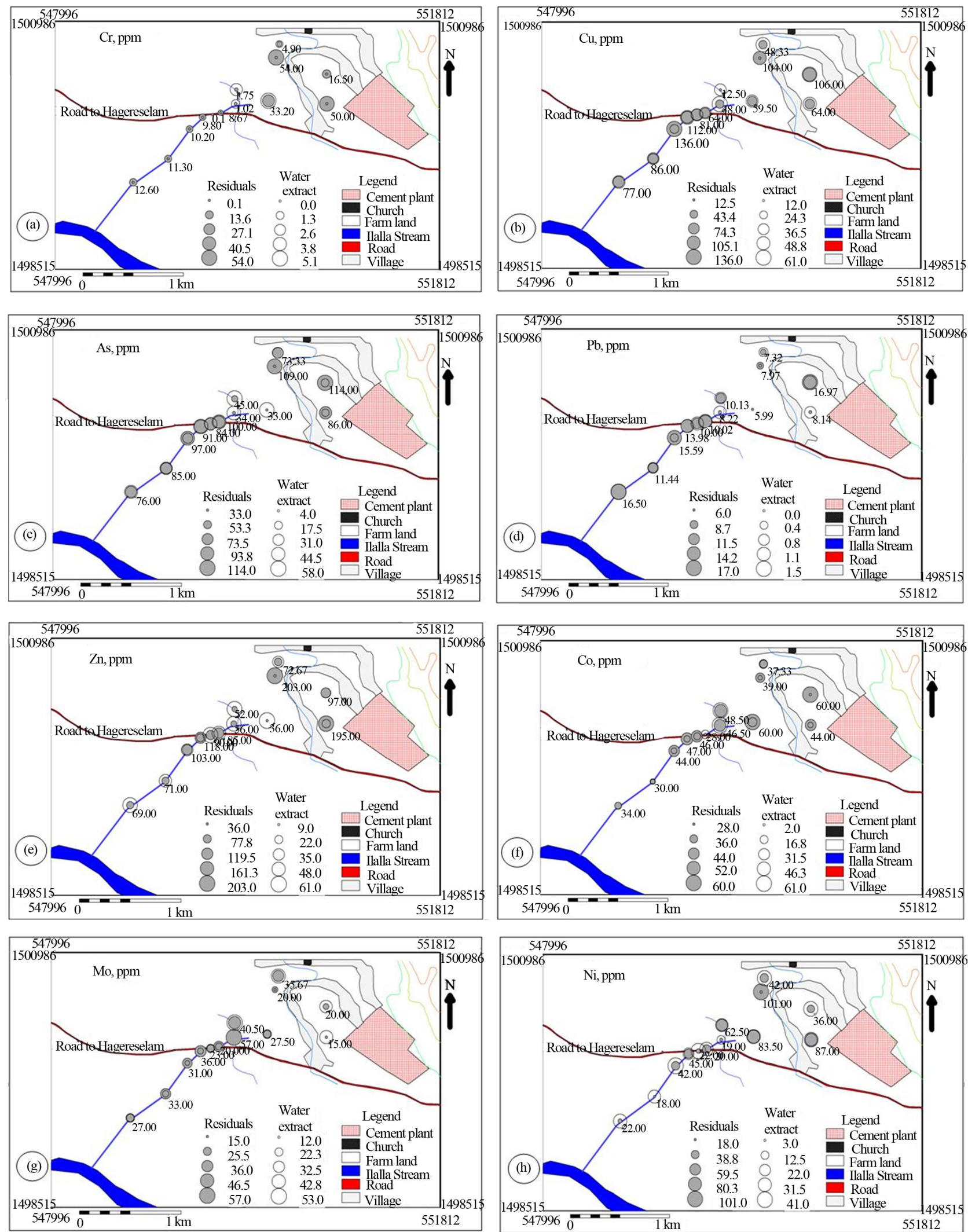

Figure 7. Post maps showing the spatial distribution of trace cations in water soluble and residual portions of soil and stream sediments. 
[25] has indicated that the distribution of calcium, magnesium, sodium and potassium was affected by dust emission from cement plants.

With regard to the trace metals, the soil has higher $\mathrm{Cr}$, As, $\mathrm{Co}$ and $\mathrm{Ni}$ in the residual and lower $\mathrm{Cr}$ and As in the water soluble fractions than the stream sediment does. The farm land has higher Mo in water soluble and comparably lower $\mathrm{Cu}$ and $\mathrm{Pb}$ in both fractions relative to the stream sediments (Figure 7). It is evident that the cement dust emission has an impact on the soil's $\mathrm{Cr}$, Co, Mo and $\mathrm{Ni}$ content which decreases dramatically downstream (Figures 7(a), (f), (g) and (h)). The spatial patterns of $\mathrm{Cu}$, $\mathrm{Pb}, \mathrm{As}, \mathrm{Zn}$ and Co show significant association with the cement dust and loadings from the traffic movement on the road. It is well documented that dust and particulates derived from cement plants as well as vehicular exhausts contain high concentrations of heavy metals, especially $\mathrm{Pb}, \mathrm{Cu}$ and $\mathrm{Zn}$ [22]. The use of leaded gasoline has been responsible for the loading of $\mathrm{Pb}$ in the surrounding lithogenic environment. Zinc is mainly derived from tyre dust, because it is used as filler during tyre manufacturing [24]. Zinc originates also from its compounds employed extensively as antioxidants and as detergent/dispersant improvers for lubricating oils in vehicles as well as from the wear and tear of tyres. Copper has been used in vehicular braking systems and in automotive radiators [22]. Contamination of soil and stream sediment with toxic metals is a frequent problem in industrialized areasand along major roads [26]. The major anthropogenic source of $\mathrm{Ni}$ is the burning of furnace oils used in cement industries to heat the kiln up [27].

\section{Conclusion}

Based on the results of this research, it can be concluded that the source of emission on the study area not only comes from the cement factory, but may be influenced by emissions of the trucks transporting cement and the general traffic flow on the main road. The soil on the farm land investigated is heavily contaminated with $\mathrm{Cr}$, $\mathrm{Co}, \mathrm{Mo}$ and $\mathrm{Ni}$ while the stream sediment in the creek below the main road is moderately polluted with $\mathrm{Pb}, \mathrm{Cu}$ and $\mathrm{Zn}$. On the other hand, according to the factor analysis results, both water soluble and insoluble phases of the samples revealed anthropogenic factor for $\mathrm{Mn}, \mathrm{Cr}$, As, $\mathrm{Co}, \mathrm{Zn}, \mathrm{Na}, \mathrm{K}, \mathrm{Cu}, \mathrm{Pb}$ and $\mathrm{N}$ and geogenic factor for $\mathrm{Ca}$, $\mathrm{Mo}, \mathrm{Mg}$, and $\mathrm{Fe}$ from both lithogenic and anthropogenic origins while $\mathrm{Na}, \mathrm{Fe}, \mathrm{Cu}, \mathrm{Pb}, \mathrm{Ni}, \mathrm{Ca}, \mathrm{As}, \mathrm{Co}, \mathrm{Zn}$ and $\mathrm{Mo}$ are defined by factor of both natural and human induced sources of metals. The sever contamination is evident to the western and north western direction towards which the wind predominantly blow from the cement factory and near the main road decreasing in the down stream direction. The research has clearly determined that the anthropogenic activities have clear impact on the physicochemical characteristics of the lithogenic environment through the dust emission.

\section{Acknowledgements}

The author wish to express his deep gratitude to the geochemical laboratory staff of Earth Sciences Depart- ment in Mekelle University for diligently and carefully analyzing the soil samples.

\section{REFERENCES}

[1] A. Abdullahi, Y. D. Usman, S. S. Noma, M. Audu, N. M. Danmoma and H. Shuaibu, "Fertility Status of Fadama Soils in Gantsare Village, Wamakko Local Government, Sokoto State as Affected by Cement Dust," Nigerian Journal of Basic and Applied Science, Vol. 18, No. 1, 2010, pp. 58-64.

[2] Z. I. Muhammad and S. Muhammad, "Periodical Effect of Cement Dust Pollution on the Growth of Some Plant Species,” Turkish Journal of Botany, Vol. 2, No. 5, 2001, pp. 19-24.

[3] R. Jain and P. L. Jain, "Pollution of Soil Due To Cement Factory near Narsingarh, Madhya Pradesh, India,” Journal of Environmental Research and Development, Vol. 1, No. 2, 2006, pp. 153-154.

[4] H. Ahiamadjie and O. K. Adukpo, "Determination of the Elemental Contents in Soils around Diamond Cement Factory, Aflao,” Research Journal of Environmental and Earth Sciences, Vol. 3, No. 1, 2010, pp. 46-50.

[5] C. O. Princewill and N. N. Adanma, "Metal Concentration in Soil and Plants in Abandoned Cement Factory," International Conference on Biotechnology and Environment Management IPCBEE, Singapore, 2011, Vol. 18, pp. 146-150.

[6] E. G. Ameh, M. S. Kolawole and E. G. Imeokparia, "Using Factor-Cluster Analysis and Enrichment Methods to Evaluate Impact of Cement Production on Stream Sediments around Obajana Cement Factory in Kogi State, North Central Nigeria,” Advances in Applied Science Research, Vol. 2, No. 1, 2011, pp. 76-89.

[7] S. S. Al-Oud, M. E. A. Nadeem, B. H. Al-Shbel, "Distribution of Heavy Metals in Soils and Plants around a Cement Factory in Riyadh City, Central Of Saudi Arabia," American-Eurasian Journal of Agriculture and Environmental Science, Vol. 11, No. 2, 2011, pp. 183-191.

[8] M. A. Addo and E. O. Darko, "Evaluation of Heavy Metals Contamination of Soil and Vegetation in The Vicinity of a Cement Factory in the Volta Region, Ghana,” International Journal of Science and Technology, Vol. 2, No. 1, 2012, pp. 40-50.

[9] S. Estifanos and A. Degefa, "Assessing the Effect of Cement Dust Emission on the Physicochemical Nature of Soil around Messebo Area, Tigray, North Ethiopia,” International Journal of Economic and Environmental Geology, Vol. 3, No. 2, 2012, pp. 12-20. 
[10] M. A. Addo, E. O. Darko, C. Gordon and B. J. B. Nyarko "Contamination of Soils and Loss of Productivity of Cowpea (Vigna unguiculata L.) Caused by Cement Dust Pollution," International Journal of Research in Chemistry and Environment,” Vol. 3, No. 1, 2013, pp. 272-282.

[11] K. Bhupander, K. Sanjay, M. Meenu, S. K. Singh, D. Prakash, C. S. Sharmal and D. P. Mukherjee, "Geochemical Fractionation of Some Heavy Metals in Soils in the Vicinity of Sukinda Mining Area, Orissa," Advances in Applied Science Research, Vol. 2, No. 5, 2011, pp. 263272.

[12] P. Vrhovnik, N. Rogan Šmuc, T. Dolenec, T. Serafimovski and M. Dolenec, "Impact of Pb-Zn Mining Activity on Surficial Sediments of Lake Kalimanci (FYR Macedonia),” Turkish Journal of Earth Sciences, Vol. 2013, No. 22, 2013, pp. 996-1009.

[13] R. Scheifler, C.Schwartz, G. Chevarria, A. De Vaufleury, P.-M. badot and J.-L. Morel, "Nonavailable Soil Cadmium Is Bioavailable to Snails: Evidence From Isotopic Dilution Experiments," Environmental Science \& Technology, Vol. 37, No. 1, 2003, pp. 81-86. http://dx.doi.org/10.1021/es025677w

[14] J. Hlavay, T. Prohaska, M. Weisz, W. W. Wenzel and G. J. Stingeder, "Determination of Trace Elements Bound to Soils and Sediment Fractions," IUPAC Technical Report, International Union of Pure and Applied Chemistry, Vol. 76, No. 2, 2004, pp. 415-442. http://dx.doi.org/10.1351/pac200476020415

[15] S. de Villiers, C. Thiart and N. C. Basson, "Identification of Sources of Environmental Lead in South Africa from Surface Soil Geochemical Maps,” Environmental Geochemistry and Health, Vol. 32, 2010, pp. 451-459. http://dx.doi.org/10.1007/s10653-010-9288-8

[16] J. Benjamin, "Wind Data Evaluation after 6 Months," Wind Energy Programme TERNA-Ethiopia Deutsche Gesellschaft ftir Technische Zusammenarbeit (GTZ) gmbH Dag-Hammarskjold-Weg 1-5, 2005.

[17] L. B. Hinrich, L. M. Brian and G. A. O’Connor, "Soil Chemistry,” 3rd Edition, John Wiley \& Sons, Inc., New York, 2001.

[18] A. Probst, L. Hernandez and J. L. Probst, "Heavy Metals Partioning in Three French Forest Soils by Sequential Extraction Procedure,” Journal De Physique IV, France,
Vol. 107, 2003, pp. 1103-1106.

[19] E. Joan, McLean and E. B. Bert, "Behavior of Metals in Soils," United States Environmental Protection Agency, EPA/540/5-92/018, 1992.

[20] O. A. Al-Khashman and R. A. Shawabkeh, "Metals Distribution in Soils around the Cement Factory in Southern Jordan,” Environmental Pollution, Vol. 140, No. 3, 2006, pp. 387-394. http://dx.doi.org/10.1016/i.envpol.2005.08.023

[21] G. M. A. Bermudez, M. Moreno, R. Invernizzi, R. Pla and L. M. Pignata, "Evaluating Top Soil Trace Element Pollution in the Vicinity of a Cement Plant and a Former Open-Cast Uranium Mine in Central Argentina,” Journal of Soils and Sediments, Vol. 10, No. 7, 2010, pp. 13081323. http://dx.doi.org/10.1007/s11368-010-0243-1

[22] G. H. Guo, F. C. Wu, F. Z. Xie and R. Q. Zhang, "Spatial Distribution and Pollution Assessment of Heavy Metals in Urban Soils from Southwest China,” Journal of Environmental Sciences, Vol. 24, No. 3, 2012, pp. 410-418. http://dx.doi.org/10.1016/S1001-0742(11)60762-6

[23] K. B. Mmolawa, A. S. Likuku and G. K. Gaboutloeloe, "A Preliminary Study Of Heavy Metal Contamination Along Major Roads In Botswana,” International Journal of Environmental Science, Management and Engineering Research, Vol. 1, No. 1, 2012, pp. 10-19.

[24] J. O. Olowoyo, E. van Heerden and J. Fischer, “Trace Metals Concentrations in Soil From Different Sites in Pretoria, South Africa," Sustainable Environmental Research, Vol. 23, No. 2, 2013, pp. 93-99.

[25] A. M. Abdel-Rahman and M. M. Ibrahim, "Effect of Cement Dust Deposition on Physiological Behaviors of Some Halophytes in the Salt Marshes of Red Sea," Egyptian Academic Journal of biological Sciences, Vol. 3, No. 1, 2012, pp. 1-11.

[26] S. S. Ahmad and S. Erum, "Integrated Assessment of Heavy Metals Pollution along Motorway M-2,” Soil \& Environment, Vol. 29, No. 2, 2010, 110-116.

[27] S. Odat and A. M. Alshammari, "Special Distribution of Soil Pollution along the Main Highways in Hail City, Saudi Arabia,” Jordan Journal of Civil Engineering, Vol. 5, No. 2, 2011, pp. 163-172. 